\title{
Examining the Influence of Physical Facilities, Customer Complaint Handling and E-service on Customer Switching Intention
}

\author{
Onyeagwara Chukwuemeka O.* \& Chukwudi I. Njelita \\ Department of Marketing, Nnamdi Azikiwe University, Awka, Nigeria
}

\begin{abstract}
The main intention of this study was to determine the drivers of customer switching behaviour in the Nigerian road transport industry using firms in the South East; while it specifically sought to: (1) determine the extent at which physical facilities drive switching behaviour among road transport customers in the South East, Nigeria; (2) determine the extent at which customer complaint handling system drives switching behaviour among road transport customers in the South East, Nigeria; (3) determination the extent at which e-service availability drives switching behaviour among road transport customers in the South East, Nigeria. The researchers adopted the cross-sectional survey research method in this study. The questionnaire served as the major instrument for primary data collection. The study focused on the customers of eight road transport firms (ABC, Peace Mass, God is Good Motors ITC, Abia Line, ESTMASS, TRACAS, and EboMass) in the South East of Nigeria. The study found positive correlation between all the variables and customer switching intention.
\end{abstract}

Keywords: physical facilities; customer complaint handling; E-service; customer switching intention.

\section{Introduction}

The new entrants of various categories into the road transport industry in the South East Nigeria, the growing impact of information and communication technology (ICT) as well as the noticeable changes in the present day customers are clear indications that the Nigerian service sector is becoming hyper competitive. An average Nigerian customer today, has at least basic education. A good number of them have access to information through the print media or broadcast media, internet, etc. Monye (2015) rightly noted that, compared with $7 \mathrm{~m}$ in 2000 , the middle class population in Nigeria is now $40 \mathrm{~m}$. Again, over $56 \mathrm{~m}$ Nigerians live in urban areas at an annul increasing rate of $3.8 \%$, over $40 \%$ of the population have access to internet and $20 \%$ now use smart phones, making e-commerce and epayment on the increase (Agu et al, 2016, Monye, 2015). These customers emphasize convenience and strong relationship in their purchases.

Given the availability of road transport services providers of different categories, who adopt various marketing strategies to attract customers, customer loyalty in the industry is at risk. Although there are numerous transporters available in every city and rural area in the South Eastern States, the operators constantly try to offer services that will ensure that customers re-patronize them. The organized and semi-organized operators endeavour to provide extra customer services, sound and modern facilities (buses, terminals, and other physical evidences), good and friendly customer relationship, customer complaint handling platforms and in some cases, scheduled services. The unorganized, open-market transport services providers recently have had improvement in the quality of vehicles they use. Though the buses may not be as attractive as the ones used by the first class organized, private owned transporters such as ABC, God is Good, Chisco, The Young Shall Grow, Peace Mass and Best Way, a good number of them compete strongly with most government owned transport companies in terms of quality of buses that ply short distances. These operators also ensure longer operating hours and early hour service provision to customers. This has created a new dimension of competition in the road transport sector, which every operator is expected to re-strategize to remain relevant.

\footnotetext{
* Corresponding author.

E-mail address: ochukwuemeka@yahoo.com
} 
The import of this scenario is that many customers of the organized road transporters are now beginning to try the services of the semi-organized and in some cases, the unorganized services providers. The customer switching actions have had noticeable effects on the market shares of operators, some positively and others negatively. For instance, the entrance of All States Transport services into the Owerri market and very close to ABC Transport, had much negative effect on the Calabar/Uyo services of ABC. According to the Operations Manager, their average monthly traffic reduced from a five-year all time average of 998 to 456 in 2018. Also, the presence of God is Good Motors directly opposite The Young Shall Grow Motors in Owerri, has also dragged the long distance (Lago, Abuja) traffic of The Young Shall Grow 37\% lower compared with the rate before the entrance of Good is Good Motors (The Young Operations Manager, 2019). One may not appreciate the rate of churn that the organized transporters suffer because of this competition since they all offer almost the same quality of services at more convenient and affordable rates.

Competition has become increasingly intense resulting in customer switching behaviour amongst customers who desire the best in terms of convenience, safety, customer friendly, timely and affordable services. It seems, however that the operators are yet unaware of the key factors that trigger such a magnitude of switching actions and their attendant marketing implications. There is urgent need to call the attention of the road transport services marketers to the marketing implication of customer switching intentions on their marketing performance. The providers would also need research based evidences of customers' views of the antecedents or drivers of switching behaviour in the road transport industry.

Reviewed literature shows that very little studies had been done in this area. The bulk of studies on customer switching behaviour in the service sector focused on the banking (Njoku et al., 2015; KPMG Consulting, 2014; Monye, 2015; Keveney, 1995), Insurance (Crosby \& Stephen, 1987) and the telecommunication (Liang et al., 2013). Studies that focused on the road transport industry are yet to be seen within published marketing literature. This is a gap that this study hopes to close using an adapted version of the Keveney (1995) model of customer switching behaviour. This adaptation is necessary given scholars' assertion that industry-specific characteristics should be considered when choosing variables for customer switching behaviour studies (Keveney, 1995; Lovelock, 1983).

The main intention of this study was to determine the drivers of customer switching behaviour in the Nigerian road transport industry using firms in the South East; while it specifically sought to:

(1) To determine the extent at which physical facilities drive switching behaviour among road transport customers in the South East, Nigeria

(2) To determine the extent at which customer complaint handling system drives switching behaviour among road transport customers in the South East, Nigeria.

(3) To determination the extent at which e-service availability drives switching behaviour among road transport customers in the South East, Nigeria.

This gives rise to the following hypotheses:

H01: There is no significant relationship between physical facilities and switching behaviour among road transport customers in the South East, Nigeria.

H02: There is no significant relationship between customer complaint handling system and switching behaviour among road transport customers in the South East, Nigeria.

H03: There is no significant relationship between e-service availability and customer switching behaviour among road transport customers in the South East, Nigeria.

\section{Review of related literature}

Consumer behavior is identifying, searching, selecting and consuming products and services for satisfying their needs and wants (Solomon et al., 2006). For Bhasin (2010), consumer behavior determines how consumers decide to buy our product and what the various factors responsible for this are". The consumer behavior study is basically, the psychology of consumers, like when, how, why and where people buy and use the products for satisfying their needs. From a marketing point of view, Perner (2006) asserted that the consumer behavior is, "the psychology of how consumers think, feel, reason and select between different alternatives like brands, products and retailers".

On the other hand, Zikiene and Bakanauskas (2006) cited in Ahmed, Gull \& Rafiq, 2015) noted that consumer switching behavior restricts companies and customers to make long-term relationships, and it breaks the predeveloped long-term relationships. Thus, consumer switching behavior is the behavior of consumers in shifting their attitude from one brand (product or service) to another brand (product or service) (Zikiene et al, 2006). Ahmed et al., 
(2015) asserted that the consumers are the key focus of marketing and even the entire business. This is following a research, which stated that every year, the $83 \%$ brand failed to achieve marketing objectives, and there are 11,000 products introduced every year and only $56 \%$ products reach to the age of 5 year or more and only $8 \%$ new ideas are converted into market offerings. For Bhasin (2010), the reason is, because any marketing idea, product or strategy, that is not focusing on the customers or not designed according to the customer's needs and wants, becomes failed or not able to deliver its full strength.

According to Chidoka (2009), the road transport system in Nigeria accounts for over $75 \%$ of mobility needs of the country. The national network is currently estimated to be $194,200 \mathrm{~km}$ of which $34,120 \mathrm{~km}(17.6 \%)$ are federal, $3050 \mathrm{~km}(15.7 \%)$ are State, while 129,580km (66.7\%) are local and rural roads (www.wikipedia.com,2011). Of these figures, $36900 \mathrm{~km}$ of federal and state main roads representing $19 \%$ are paved, while $25,700 \mathrm{~km}(13 \%)$ are unpaved. Also, $21,900 \mathrm{~km}, 72,800 \mathrm{~km}$ and $35,900 \mathrm{~km}$ representing $11 \%, 38 \%$ and $19 \%$ are urban roads, main rural roads and village access roads respectively (CBN Statistical Bulletin, 2003). In fact, the CIA World Fact Book (2009) stressed that Nigeria has the largest road network in West Africa and the second largest South of the Sahara. It is sad to note that even the federal road networks are largely unmotorable, how much less the state and local roads that have the largest shares of the road network system in the country.

Nevertheless, the road transport segment has continued to lead other segments of the transport system in their contributions to the Gross Domestic Product (GDP) of the nation. In 2009, over 90\% of the contribution of the transport sector to Nigeria's GDP was from the road segment. The CBN Statistical Bulletin (2011) shows that between 2001 and 2005, the aviation segment contributed $0.04 \%, 0.05 \%, 0.04,0.04$ and 0.05 respectively, while ocean contributed $0.19 \%, 0.21 \%, 0.24 \%, 0.26 \%$ and $0.20 \%$ respectively. The bulk of the contributions of the transport sector to GDP since 1981 come from the road segment with $5.93 \%$ as the highest ever in $1982,2.77 \%$, $2.97 \%, 2.96 \%, 4.08 \%$ and $5.29 \%$ from 2001 to 2005 respectively.

Scholars such as Keveney (1995), Burnham, Frels and Mahajan (2003), Grzybowski (2004), Serkan and Ozer (2005), Chu (2009), Vyas and Raitani (2013) and Onyeagwara and Agu (2016) have identified some drivers of switching behaviour in the service industry. Such drivers include switching cost and trust, service quality, reputation, reliability, empathy, assurance, responsiveness, tangibles, customer commitment, , price, effective advertising competition, responses to service failure, customer satisfaction, involuntary switching and service products.

In the transportation industry, Modern (1991) as cited in Inyanga, (2004) identified the factors that influence patronage of certain transportation carriers as cost, speed, reliability, accessibility, security, dependability, customer service distance, operational capability etc. the road transport segment faces serious challenges such as: poor road facilities, weak regulatory framework, increasing rate of accident, presence of many unorganized operators etc. These problems cause dissatisfaction on customers, which also result in complaints.

However, this study seeks to find out the effect of physical facilities, customer complaint-handling system and eservice availability on the switching behaviour of road transport customers in the South East, Nigeria.

\subsection{Complaints handling and customer switching intention}

It is agreed that the merchant's commitment to consumers is demonstrated by promptly resolving and dealing with complaints in a way that is fully satisfactory to the consumer (Anderson \& Swaminathan, 2011; Davidow, 2003). This commitment refers to the strength of the ongoing relationships with the consumers. Hong and Lee (2005) argued that if responsiveness to complaint appears to be effective and genuine, consumers are more satisfied than they would have been if no complaint had occurred at all. The study conducted by Bitner and Bernard (1990) shows that, it is not necessarily transaction failures that cause dissatisfaction because consumers accept that sometimes problems occur that are not within the merchant's control. Rather, it is the merchant's responsiveness to respond promptly to complaints and to effectively compensate for the problems caused. Hennig-Thurau et al. (2010) opined that the opportunity for consumers to voice their complaints to a broader public poses new challenges for merchants. This supports the assertion of Ward and Ostrom (2006) that due to the rise of web 2.0, complaining has changed from a private phenomenon into a public phenomenon.

\subsection{The Theory of Habitual Behaviour}

Habitual behaviour is a form of automatic and routine behaviour. People repeat such behaviour, because it is easy, comfortable or rewarding. It is efficient to do something by habit, and not to constantly reason with oneself about 
what is the best thing to do. The intrinsic advantages of the behaviour outweigh the possible disadvantages. 'Intrinsic' because, in the case of habitual behaviour, there is no constant weighing of pros and cons. In the mechanism of the theory, the 'plusses' (at the right in the model) weigh against the 'minuses' and change the originally planned behaviour into a habit. Through repetition, a 'loop' and an automatism develop: reasoned weighing does not occur every time, but only when the loop is broken. Removing incentives that support the habitual behaviour; making consumers aware of their habitual behaviour, and enabling them to avoid or control the negative outcomes and provide positive alternatives. In this way we can learn, and teach, new desired habits

\subsection{Empirical framework}

Gordon (2003) investigated the impact of customer commitment on switching intention and find out that committed banking customers were less likely to switch in comparison with those who lacked commitment towards their banks. Miranda, Konya and Havrila (2005) identified store attributes as multi dimensional construct including location of store, nature and quality of stocks, in-store promotions, sales personnel, physical attribute, and convenience of store, atmospherics and loyalty cards that influence consumer attitude or behaviour.

The purpose of the study of Bhatt and Bamrara (2012) was to examine the complaint behaviour of customer and specific factors towards switchover of mobile service providers. Several hypotheses were extracted from the research framework and are tested using chi-square and ANOVA analysis. The area covered under this study was Haridwar and Dehradun due to availability of well mixed population base in Uttarakhand. A well-structured questionnaire was designed. A sample of 300 respondents (customer of prepaid or post paid mobile services) was used and clustersampling method was applied for the purpose. The study concluded that most of the customers were satisfied with their service providers but were interested in switching over. They claim that network problem such as poor connectivity and high prices were the main reasons which influenced and forced them to switch to another operator who is perceived better offers/schemes and value added service plays the least important role.

The study of Johnston (2001) mentioned that complaint management should lead to operational improvement and improved financial performance should attain customer satisfaction. Many organizations ignore the operational value of complaints and as a result, many complaint processes seem geared to trying to mollify customers rather than ensuring that problems do not reoccur. Using data from an empirical benchmarking study, based on a detailed questionnaire completed by customer service managers in $40 \mathrm{UK}$ organizations, the relationships between seven key variables, complaint processes, satisfaction, retention, process improvement, employee attitude, retention and financial performance are calculated and a relationship model developed. The results expose significant correlations between all variables in the model, as a result four acid tests of complaint management are proposed. It is suggested that financial improvements may be better leveraged by bringing about organizational improvements and by ensuring complaint processes are "staff-friendly", rather than simply trying to satisfy customers.

In their study, Rothenberger, Grewal \& Iyer (2008) explored the role of 5 drivers of loyalty: customer usage level, service pricing, service quality, membership in the firm's loyalty program, and satisfaction with complaint handling. The effects of these drivers may differ for customers who complain versus who do not complain. The questionnaire of this study was administrated to passengers of a major European airline. On randomly selected routes between Germany, Austria, and Switzerland, passengers were randomly selected flights and seat numbers received questionnaires with total amount of two thousands and six hundreds. The researchers found that the satisfaction with complaint handling was key to consumer recommendation of the service to others.

The study of Agu, Samuel and Ikenna (2019) aimed at assessing the impact of effective customer touch point management on the performance (profitability, patronage level, market share and image) of commercial banks and on customers' satisfaction. The cross-sectional survey research design was adopted while a sample size of 130 respondents made up of First and Zenith Banks Staff and customers in Owerri Metropolis was used. Stated hypotheses were tested using the Chi-square. It was discovered among others that most customer touchpoint management strategies in commercial banks in Owerri were still ineffective and inefficient and that effective customer touchpoint management has significant impact on banks' performance and customers' satisfaction. The study recommended among others that commercial banks should identify and effectively manage the basic customer touchpoints and conduct periodic marketing research to assess customers' view of the efficiency and effectiveness of their touchpoints management efforts.

Ogbonna (2018) conducted a study on the relationship between e-marketing and marketing performance Among SMEs in Abia State. 140 staff of Udeagbala Holdings, Star-line Nigeria, Zan Cosmetics and Iheakason Group were 
conveniently used. Correlation and descriptive statistics were used in analyzing data obtained. The findings of the study show that a positive correlation exists between e-marketing and sales volume, social media marketing and market share. Also, factors such as security, technological factors, environmental, organizational and energy supply affect the adoption of e-marketing and marketing performance in Abia State. The study recommended that the management of SMEs should encourage e-marketing platform in order to increase sales volume, government should help in the availability of power supply.

Njoku and Chiana (2019) embarked upon a study to unearth the impact of E-Marketing adoption on marketing success of Small Business enterprises in Abia State, Nigeria. Primary and secondary sources of data were extensively employed. A sample size of 369 was determined using proportion method and was used for the study. The stated hypotheses were tested at 0.05 level of significance with simple regression in SPSS version 20. The paper revealed that e-marketing significantly impacts marketing performance and marketing effectiveness of SMEs in Aba, especially in the areas of profitability, market share, customer satisfaction, sales turnover, return on investment, reduction of sales cost, increased brand equity. The paper recommended that small business enterprises should imbibe the culture of training their staff periodically concerning e-marketing tools applications in their day to day activities. It further recommended that government should assist small business enterprises in the provision of basic amenities like stea dy power supply, internet facilities, conducive environment etc, so that they can compete favourably with their counterparts in the developed economies of the world, among others.

Ejiofor (2017) carried out a study on challenges to online shopping in a typical emerging market using selected online shoppers in Asaba, Nigeria. 140 respondents were involved. Results of the multiple regressions show that three of the four factors negatively affect and reduce the frequency with which consumers visit online shops. The study discovered that there are some implications for online marketers and policy makers. Network security and reliability need to be addressed. The study therefore recommended that online marketers need to present attractive websites with wellstructured information to delight online shoppers. The study further recommended the need for sensitization of potential customers on the safety and convenience of online shopping, among others.

The objective of paper presented by Kumar and Dash (2015) was to develop a conceptual model to examine the relationships among e-service quality dimensions and willingness to buy from electronic stores. Data from an offline survey of 513 consumers was analyzed with the partial least squares (PLS) structural equation modeling (SEM) technique. The high fit indexes and the theoretically consistent parameter estimates suggest that the structural model fits the data well. The findings showed that e-service quality dimensions: web site design, assurance, reliability and empathy have the positive correlation with willingness to buy and directly impact on customers buying behaviour except responsiveness. The significance of this study is that it provides a model of e-service quality and customers' willingness to buy. Limitations and future research are also discussed.

\section{Research methodology}

The researchers adopted the cross-sectional survey research method in this study. The questionnaire served as the major instrument for primary data collection. The study focused on the customers of eight road transport firms (ABC, Peace Mass, God is Good Motors ITC, Abia Line, ESTMASS, TRACAS, and EboMass) in the South East of Nigeria. The sample size for the study was 371 customers of the selected transport firms. Again, primary data were analyzed using tables, charts and simple percentages. On the other hand, stated hypotheses were tested using multiple regression analysis at 0.05 level of significance in SPSS version 21 .

The direct effect research model for this study is of the form:

\section{$\mathrm{CSB}=\mathbf{f}(\mathrm{PF}, \mathrm{CCHS}, \mathrm{ESA})$}

where:

CSB is Customer Switching Behaviour;

$\mathrm{PF}$ is physical facilities

CCHS is Customer complaint handling system

ESA is E-service availability

The composition, direction and relative strength of each of the six independent variables on the single dependent variable (CSB) was determined. 
In order to validate (accept) or nullify (reject) any stated hypothesis tested with the multiple regression, major attention was paid to the P-values of the tested constructs. Therefore, we will reject the null hypotheses where the SPSS p-values are less than alpha (0.05) and the alternative hypotheses accepted.

\section{Results and Discussions}

4.1. Data presentation and analysis

Table 1. Questionnaire distribution

\begin{tabular}{lllll}
\hline Transport Company & $\begin{array}{l}\text { Number of Copies } \\
\text { Distributed }\end{array}$ & $\begin{array}{l}\text { Number of Copies } \\
\text { Retrieved and Used }\end{array}$ & Number of Lost & $\begin{array}{l}\text { Percentage of } \\
\text { Valid/Used Copies }\end{array}$ \\
\hline ABC & 28 & 19 & 9 & 6.00 \\
Peace Mass & 39 & 28 & 11 & 9.00 \\
God is Good & 14 & 14 & 0 & 5.00 \\
ITC & 110 & 98 & 12 & 32.00 \\
Tracass & 27 & 20 & 7 & 7.00 \\
AbiaLine & 57 & 46 & 11 & 15.00 \\
ESTMASS & 67 & 59 & 8 & 19.00 \\
Ebotrans & 29 & 22 & 7 & 7.00 \\
Total & $\mathbf{3 7 1}$ & $\mathbf{3 0 6}$ & $\mathbf{6 5}$ & $\mathbf{1 0 0}$ \\
\hline
\end{tabular}

Source: Field Survey, 2020

Table 1 showed that out of the 371 copies of the questionnaire distributed to respondents, 306 copies were retrieved. This was $82 \%$ of the sample size. However, out of the total number distributed, 65 copies were lost completely.

Table 2. Whether respondent had switched transport firms

\begin{tabular}{lll}
\hline Responses & Frequency & Percentage \\
\hline Yes & 171 & 56.00 \\
No & 135 & 44.00 \\
Total & $\mathbf{3 0 6}$ & $\mathbf{1 0 0}$ \\
\hline
\end{tabular}

Source: Field Survey, 2020

This is further presented in figure 1 thus:

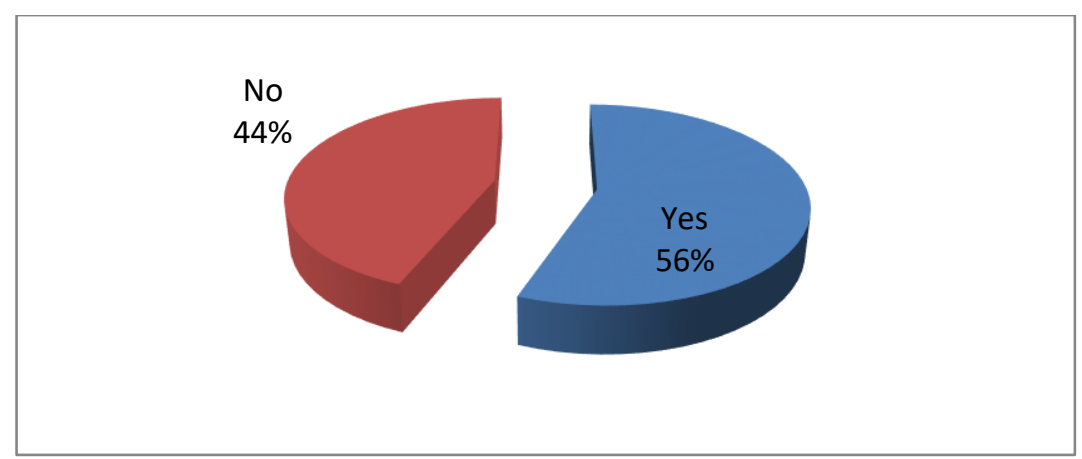

Figure 1. Pie chart on Responses to Switching

Table 2 and figure 1 show that out of the total number of respondents, $17(56 \%)$ respondents had switched transport service providers; while 135 (44\%) respondents had not switched transport service providers. 
Table 3. Reasons for switching transport service providers

\begin{tabular}{lll}
\hline Option & Frequency & Percentage \\
\hline Poor service quality & 158 & 92.00 \\
Price factors & 116 & 68.00 \\
More enticing promotional incentives by other firms & 98 & 57.00 \\
Location factors & 101 & 59.00 \\
Poor complaint handling system & 132 & 77.00 \\
Obsolete and unattractive facilities & 141 & 82.00 \\
\hline
\end{tabular}

Source: Field Survey, 2020

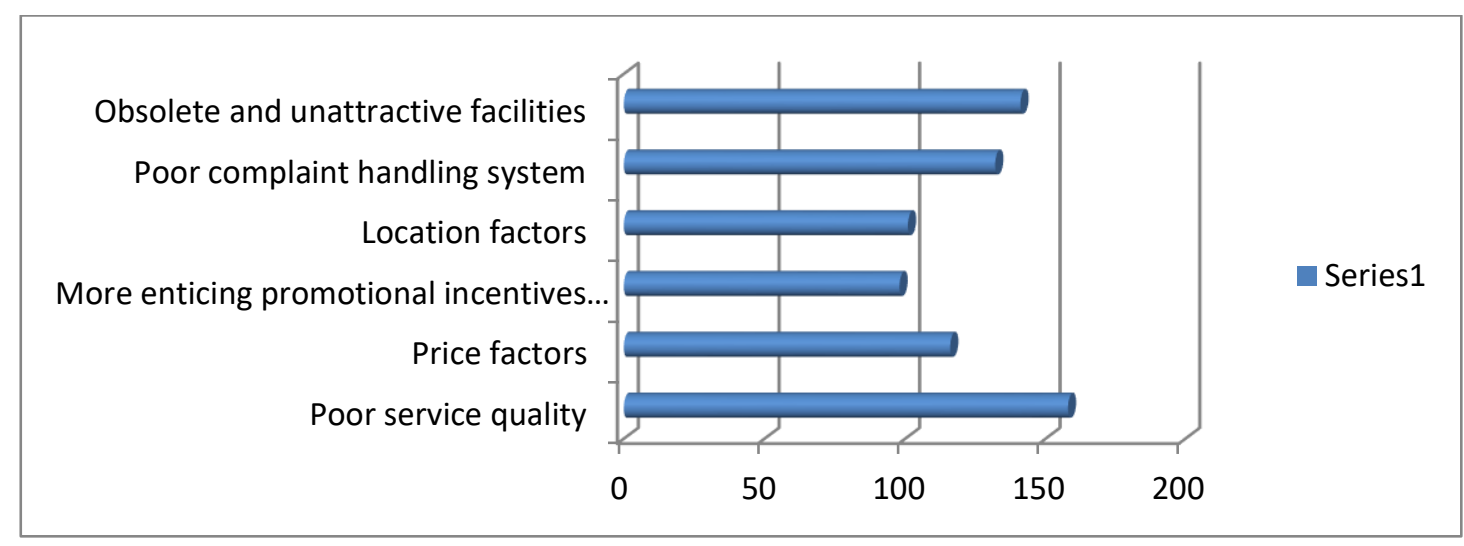

Figure 2. Bar chart showing reasons for switching transport service providers

Among the 171 respondents that have switched transport firms, data displayed in table 3 and figure 2 show that the respondents identified six factors that influence customer switching of transport firms. Thus, 158 (92\%) respondents, $116(68 \%)$ respondents, $98(57 \%)$ respondents, $101(59 \%)$ respondents, $132(77 \%)$ respondents and $141(82 \%)$ respondents identified poor service quality, price factors, more enticing promotional incentives by other firms, location factors, poor complaint handling system and obsolete and unattractive facilities, respectively as factors that cause customers to switch transport firms.

Table 4. Responses to questions relating to customer loyalty (Revised for switching intention)

\begin{tabular}{lllllll}
\hline Statement & SA & A & UN & D & SD & TOTAL \\
\hline I was willing to continuously re-patronize my chosen transporter. & 186 & 96 & 30 & 15 & 9 & 336 \\
I had in the past recommended the firm to others & 156 & 69 & 45 & 21 & 15 & 306 \\
It was my intention to remain with the firm if the firm had met my & 174 & 90 & 21 & 12 & 9 & 306 \\
expectations. & & & & & \\
$\begin{array}{l}\text { I was willing to contribute my suggestions to the firm to put things } \\
\text { right. }\end{array}$ & 126 & 117 & 36 & 15 & 12 & 306 \\
The level of loyalty I intended to keep in the firm was so strong that I & 90 & 114 & 57 & 15 & 30 & 306 \\
would have been rewarded in the near future. & & & & & & \\
The trust I had in the firm triggered my repeat purchase. & 183 & 87 & 18 & 12 & 6 & 306 \\
Initially, I perceived high customer values from the services of the & 177 & 78 & 24 & 15 & 12 & 306 \\
firm. & & & & & & \\
\hline $\begin{array}{l}\text { Total } \\
\text { Average }\end{array}$ & $\mathbf{1 0 9 2}$ & $\mathbf{6 5 1}$ & $\mathbf{2 3 1}$ & $\mathbf{1 0 5}$ & $\mathbf{9 3}$ & $\mathbf{2 1 7 2}$ \\
Percentage & $\mathbf{5 1}$ & $\mathbf{9 0}$ & $\mathbf{3 3}$ & $\mathbf{1 5}$ & $\mathbf{1 2}$ & $\mathbf{3 0 6}$ \\
\hline
\end{tabular}

Source: Field Survey, 2020 


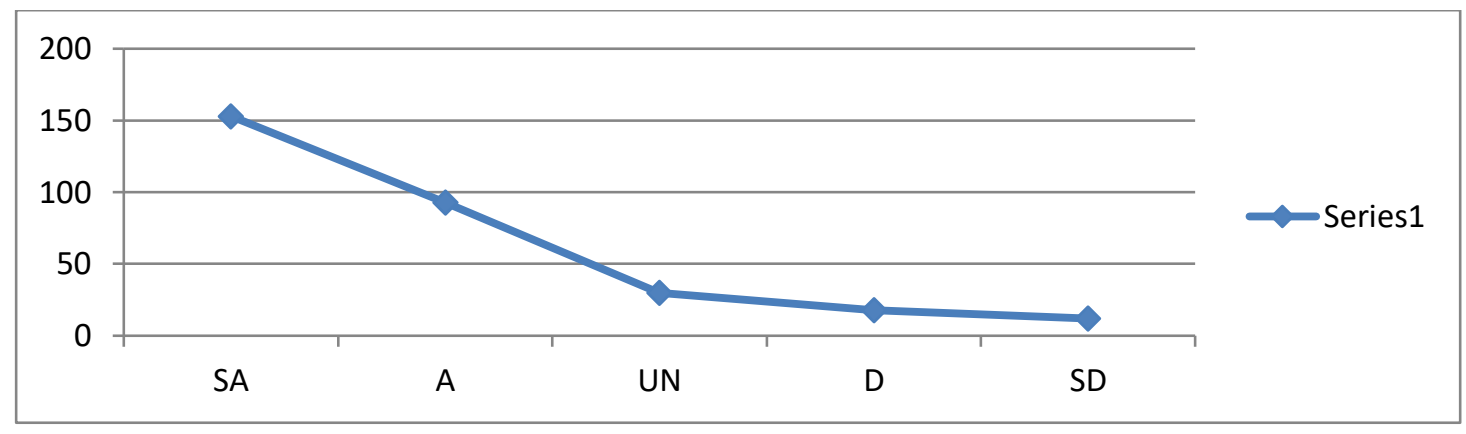

Figure 3. Line graph showing responses to questions relating to customer loyalty

Table 4 and figure 3 showed that on the average, $156(51 \%)$ respondents, 90 (29\%) respondents, 33 (11\%) respondents, $15(5 \%)$ respondents and $12(4 \%)$ respondents strongly agreed, agreed, were indifferent, disagreed and strongly disagreed respectively on the questions relating to the effect of customer loyalty on customer switching behaviour.

Table 5. Responses to questions relating to physical facility

\begin{tabular}{|c|c|c|c|c|c|c|}
\hline Statement & SA & A & UN & $\mathrm{D}$ & $\mathrm{SD}$ & TOTAL \\
\hline The buses that ply the road became obsolete and unsafe. & 135 & 126 & 27 & 12 & 6 & 306 \\
\hline The physical environment of the firm deteriorated. & 156 & 90 & 33 & 18 & 9 & 306 \\
\hline $\begin{array}{l}\text { There were no longer convenient spaces for customers to stay in the } \\
\text { terminal. }\end{array}$ & 186 & 96 & 12 & 9 & 3 & 306 \\
\hline Modern facilities for quick services in the firm were lacking. & 168 & 102 & 15 & 15 & 6 & 306 \\
\hline Staff appearance became unattractive. & 135 & 141 & 18 & 6 & 6 & 306 \\
\hline Total & 780 & 555 & 105 & 60 & 30 & 1530 \\
\hline Average & 156 & 111 & 21 & 12 & 6 & 306 \\
\hline Percentage & 51 & 36 & 07 & 04 & $\mathbf{0 2}$ & 100 \\
\hline
\end{tabular}

Source: Field Survey, 2020

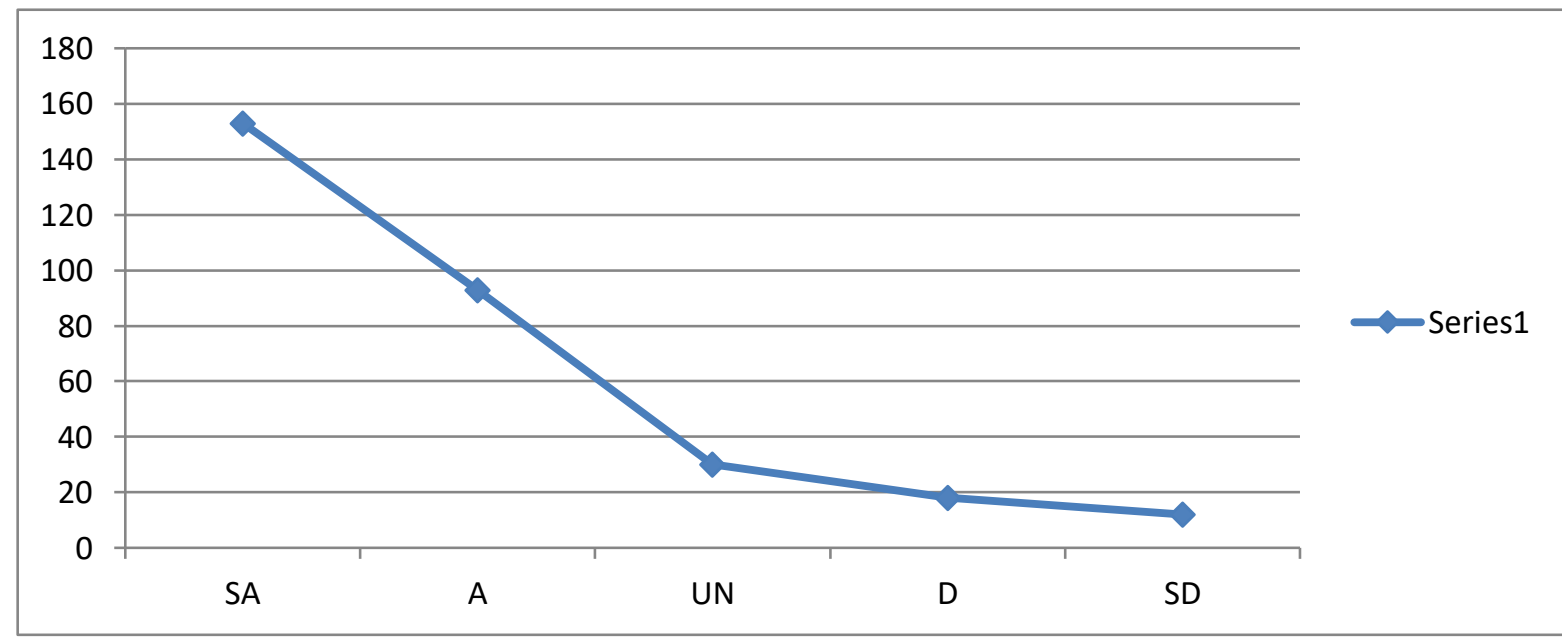

Figure 4. Line graph showing responses to questions relating to physical facility

Table 5 and figure 4 showed that on the average, 156 (51\%) respondents, 111 (36\%) respondents, 21 (7\%) respondents, $12(4 \%)$ respondents and $6(2 \%)$ respondents strongly agreed, agreed, were indifferent, disagreed and 
strongly disagreed respectively on the questions relating to the effect of physical facilities on customer switching behaviour.

Table 6. Responses to questions relating to customer complaints handling

\begin{tabular}{|c|c|c|c|c|c|c|}
\hline Statement & SA & $\mathbf{A}$ & $\mathbf{U N}$ & D & SD & TOTAL \\
\hline The complaints of customers were no longer valued. & 180 & 99 & 15 & 9 & 3 & 306 \\
\hline Complaints were not promptly handled. & 174 & 84 & 24 & 15 & 9 & 306 \\
\hline $\begin{array}{l}\text { The handling system and outcome were largely } \\
\text { subjective and unsatisfactory. }\end{array}$ & 183 & 87 & 24 & 6 & 6 & 306 \\
\hline Customers' suggestions were hardly considered. & 156 & 96 & 36 & 12 & 6 & 306 \\
\hline No clear system of complaint lodging and tracking. & 177 & 99 & 21 & 3 & 6 & 306 \\
\hline Total & 870 & 465 & 120 & 45 & 30 & 1530 \\
\hline Average & 174 & 93 & 24 & 9 & 6 & 306 \\
\hline Percentage & 57 & 30 & 08 & 03 & 02 & 100 \\
\hline
\end{tabular}

Source: Field Survey, 2020

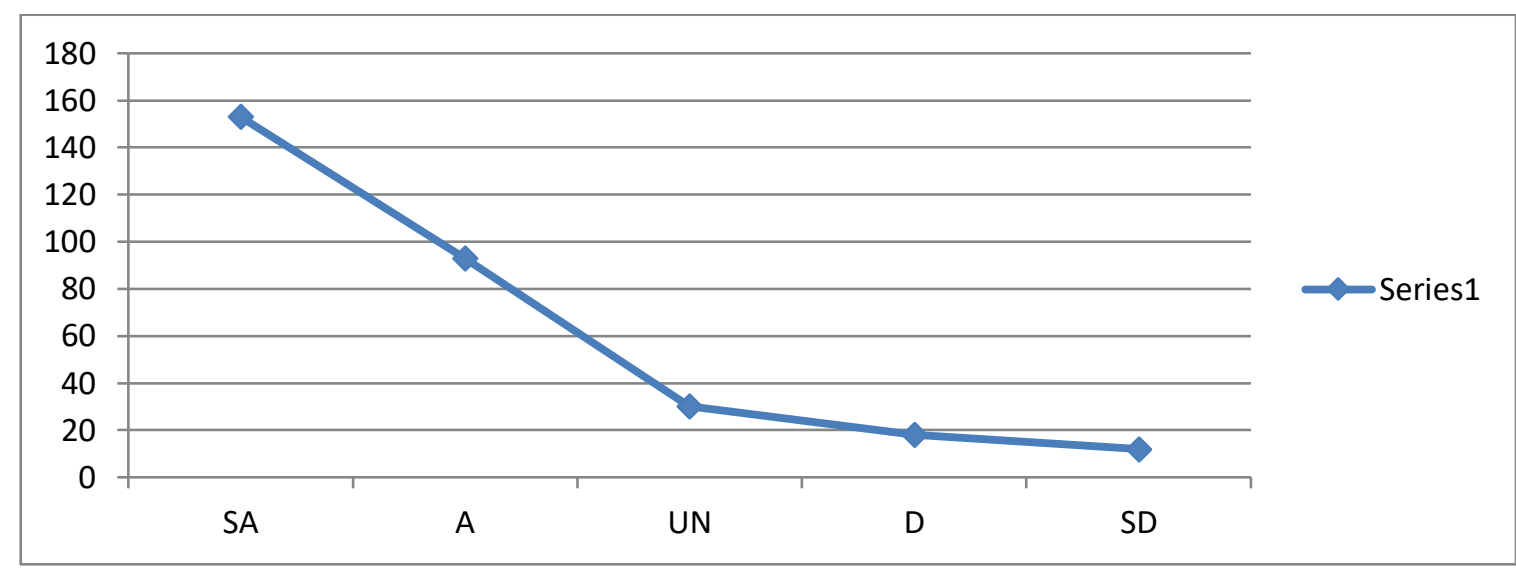

Figure 5. Line graph showing responses to questions relating to customer complaints handling

Table 6 and figure 5 showed that on the average, 174 (57\%) respondents, 93 (30\%) respondents, 24 (8\%) respondents, $9(3 \%)$ respondents and $6(2 \%)$ respondents strongly agreed, agreed, were indifferent, disagreed and strongly disagreed respectively on the questions relating to the effect of customer complaints handling on customer switching behaviour.

Table 7. Responses to questions on e-service availability

\begin{tabular}{|c|c|c|c|c|c|c|}
\hline Statement & SA & $\mathbf{A}$ & $\mathbf{U N}$ & D & SD & TOTAL \\
\hline $\begin{array}{l}\text { I consider transport firms that have online booking platforms when } \\
\text { choosing a firm to patronize }\end{array}$ & 148 & 111 & 34 & 10 & 3 & 306 \\
\hline $\begin{array}{l}\text { If a transport firm does not have online platforms for inquiries, I may not } \\
\text { patronize it }\end{array}$ & 47 & 128 & 111 & 13 & 7 & 306 \\
\hline $\begin{array}{l}\text { I may not patronize transport firms that do not have online platform for } \\
\text { complaint lodging }\end{array}$ & 77 & 128 & 87 & 7 & 7 & 306 \\
\hline $\begin{array}{l}\text { I check through the websites of road transport firms when making my } \\
\text { travel decisions }\end{array}$ & 111 & 127 & 37 & 7 & 24 & 306 \\
\hline Total & 383 & 494 & 269 & 37 & 41 & 1224 \\
\hline Average & 96 & 124 & 67 & 9 & 10 & 306 \\
\hline Percentage & 31 & 41 & 22 & 3 & 3 & 100 \\
\hline
\end{tabular}

Source: Field Survey, 2020 


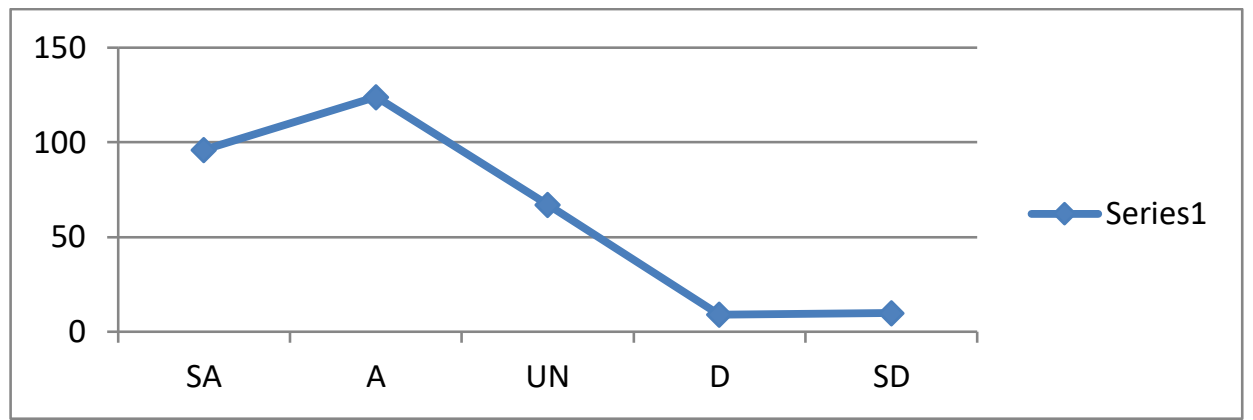

Figure 6. Line graph showing responses to questions relating to e-service availability

Table 7 and figure 6 showed that on the average, 96 (31\%) respondents, $124(41 \%)$ respondents, 67 (22\%) respondents, $9(3 \%)$ respondents and $10(3 \%)$ respondents strongly agreed, agreed, were indifferent, disagreed and strongly disagreed respectively on the questions relating to the effect of e-service on customer switching behaviour.

\subsection{Test of Hypotheses}

In this section, the three stated hypotheses were tested using the multiple regression analysis. The SPSS output is displayed thus:

\begin{tabular}{|l|r|r|r|r|r|}
\hline Model & \multicolumn{6}{|c|}{ Model Summary } \\
\hline 1 & $.966^{\mathrm{a}}$ & .932 & $\begin{array}{c}\text { Adjusted R } \\
\text { Square }\end{array}$ & $\begin{array}{c}\text { Std. Error of the } \\
\text { Estimate }\end{array}$ & Durbin-Watson \\
\hline
\end{tabular}

a. Predictors: (Constant), Customer Switching and e-service availability, Customer Switching and Complaints Handling, Customer Switching and Physical Facilities

b. Dependent Variable: Customer Switching Behaviour

\begin{tabular}{|rl|r|r|r|r|r|}
\hline Model & & Sum of Squares & df & Mean Square & F & Sig. \\
\hline \multirow{2}{*}{1} & Regression & 322.690 & 3 & 107.563 & 1353.506 & $.000^{\mathrm{b}}$ \\
& Residual & 23.444 & 295 & .079 & & \\
& Total & 346.134 & 298 & & & \\
\hline
\end{tabular}

a. Dependent Variable: Customer Switching Behaviour

b. Predictors: (Constant), Customer Switching and e-service availability, Customer Switching and

Complaints Handling, Customer Switching and Physical Facilities

Coefficients $^{\mathbf{a}}$

\begin{tabular}{|c|c|c|c|c|c|c|}
\hline \multirow{2}{*}{\multicolumn{2}{|c|}{ Model }} & \multicolumn{2}{|c|}{ Unstandardized Coefficients } & \multirow{2}{*}{$\begin{array}{c}\text { Standardized } \\
\text { Coefficients }\end{array}$} & \multirow[t]{2}{*}{$\mathrm{t}$} & \multirow[t]{2}{*}{ Sig. } \\
\hline & & $\mathrm{B}$ & Std. Error & & & \\
\hline \multirow{4}{*}{1} & (Constant) & -.709 & .081 & & -8.766 & .000 \\
\hline & $\begin{array}{l}\text { Customer Switching and } \\
\text { Physical Facilities }\end{array}$ & .787 & .068 & 669 & 11.659 & .000 \\
\hline & $\begin{array}{l}\text { Customer Switching and } \\
\text { Complaints Handling }\end{array}$ & .144 & .066 & .121 & 2.176 & .003 \\
\hline & $\begin{array}{l}\text { Customer Switching and e- } \\
\text { service availability }\end{array}$ & .222 & .035 & .200 & 6.314 & .000 \\
\hline
\end{tabular}

a. Dependent Variable: Customer Switching Behaviour 
Residuals Statistics ${ }^{\mathrm{a}}$

\begin{tabular}{|l|r|r|r|r|r|}
\hline & Minimum & Maximum & \multicolumn{1}{c|}{ Mean } & Std. Deviation & $\mathrm{N}$ \\
\hline Predicted Value & .4434 & 5.0522 & 4.1906 & 1.04060 & 299 \\
Residual & -.74778 & .55660 & .00000 & .28048 & 299 \\
Std. Predicted Value & -3.601 & .828 & .000 & 1.000 & 299 \\
Std. Residual & -2.653 & 1.974 & .000 & .995 & 299 \\
\hline
\end{tabular}

a. Dependent Variable: Customer Switching Behaviour

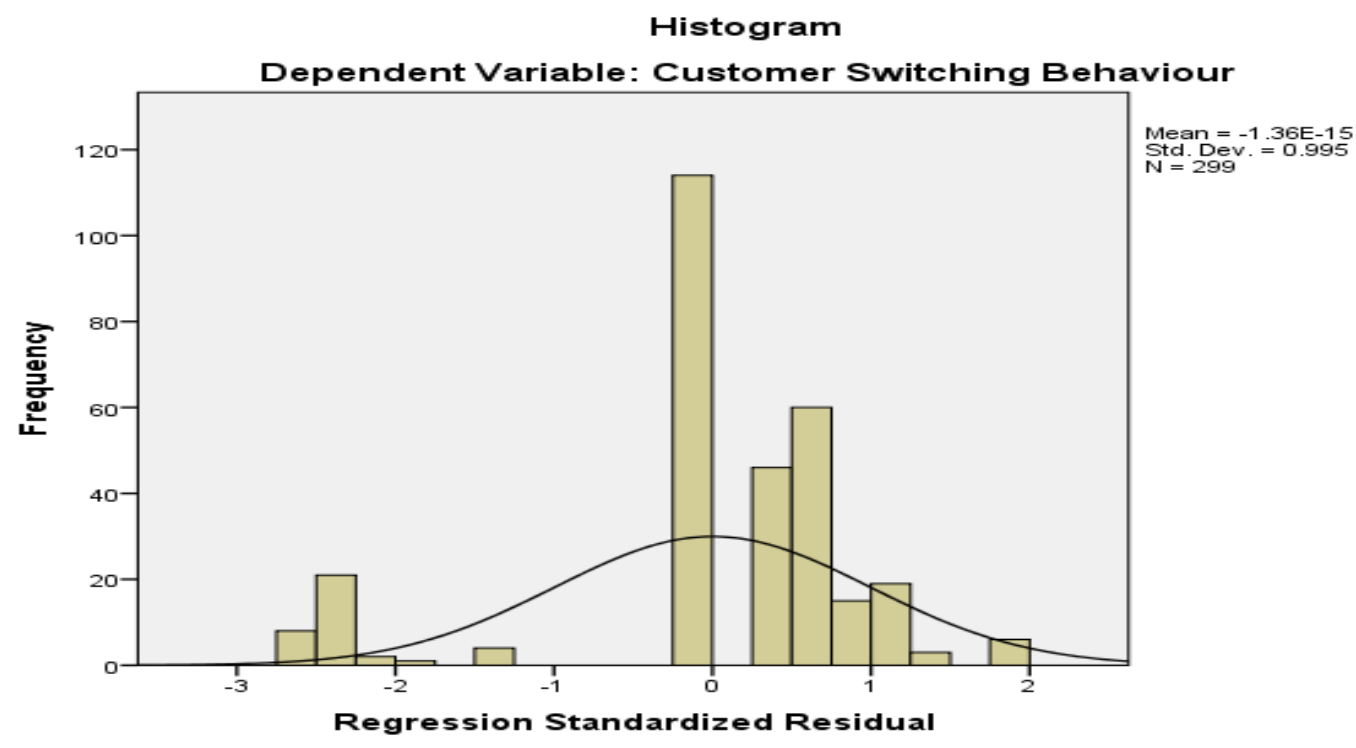

Table 8. Summary of Test of Hypotheses One to Six

\begin{tabular}{lllllll}
\hline S/N & Description & Variable & P-Value & $\begin{array}{l}\text { T-Value } \\
\text { Calculated }\end{array}$ & $\begin{array}{l}\text { T-Value } \\
\text { Critical }\end{array}$ & Decision \\
\hline 1 & Hypothesis One & Physical Facilities & .000 & 3.683 & 1.960 & Reject Null \\
2 & Hypothesis Two & Complaint Handling & .000 & 3.683 & 1.960 & Reject Null \\
3 & Hypothesis Three & E-service availability & .000 & 11.765 & 1.960 & Reject Null \\
\hline
\end{tabular}

Source: SPSS Output, 2020

Interpretation: The $\mathrm{R}$ value (.966) shows that a very strong, positive and significant relationship exists between the identified drivers and customer switching intention. The adjusted R2 value (.932) reveals that 93.2\% variation in switching intention is predicted by the three variables. Also, the F value (1353) and p value (0.000) which are greater than $f$ critical value at 0.05 level of significance (6.39) and less than alpha (0.05) respectively are positive signs of relationship. The Durbin Watson test (1.740) shows that the residuals from the linear regression are independent and there is no first order linear autocorrelation. Since the values fall between $1.707<\mathrm{d}>1.831$ and they tend to be closer to 4 as against 0 .

The coefficients table shows that physical facilities $(\mathrm{t}=11.659 ; \mathrm{p}=0.000)$, complaint handling $(\mathrm{t}=2.176 ; \mathrm{p}=0.003)$ and e-service availability $(\mathrm{t}=6.314 ; \mathrm{p}=0.000)$ are significant predictors of online switching intention. This is because their p-values are less than alpha (0.05) and their t-values greater than t-critical (1.960).

Decision: Since F calculated (1353.506) is greater than F critical (6.39) and the p value (0.000) is less than alpha (0.05), we therefore reject all the null hypotheses and accept the alternative hypotheses. This states that there is positive relationship between (physical facilities, complaint handling and e-service availability) and customer switching intention in the road transport industry in South East Nigeria. Again. 


\section{Summary, conclusion and recommendations}

\subsection{Summary}

Based on the statistical analyses, the major findings indicated that:

(1) That physical facilities are significant predictors of road transport customer switching behaviour. This implies that firms with deteriorating and unsafe buses, unhealthy physical environment, un-conducive waiting lounge, poor staff appearance and absence of modern infrastructure for quicker service delivery will witness massive customer churn. $87 \%$ positive votes were credited to this factor.

(2) That there is a significant relationship between the customer complaint resolution system of road transport firms and customer switching behaviour. This means that Firms that do not value customer complaints, fail to resolve complaints promptly, institute largely subjective and unsatisfactory complaint handling system, neglect customer suggestions and feedback and lack clear customer complaint lodging and tracking procedure will experience the whip of customer switching. Also, $87 \%$ positive votes were got on this.

(3) With a $72 \%$ affirmative responses, our study shows that e-service availability drives customer switching decision in the road transport sector in South East Nigeria.

\subsection{Conclusion}

Although studies abound on the Nigerian road transport industry, this study was based on the notion that good understanding of the reasons for customer switching is required to compete effectively in the present Nigerian road transport industry. We used an adapted version of the Keveney (1995) and Onyeagwara and Agu (2017) models of customer switching behaviour to explore the switching behaviour of customers of road transport firm in the SouthEast. It is an extension of the literature and empirical researches on the switching behaviour of customers in the sector. Thus, three key drivers of customer loyalty were considered in this study including physical facilities, complaint handling system and e-service availability. The study found positive correlation between all the variables and customer switching intention.

\subsection{Recommendations}

Based on the findings of this study, the following recommendations are hereby made:

(1) To deal with customer churn and avoid same, transport firms are encouraged to put an eye on their facilities. This is by using modern and safe buses, ensuring healthy physical environment, conducive waiting lounge, attractive staff appearance and modern infrastructure for quicker service delivery.

(2) An effective customer compliant handling system is advocated for as this will strengthen customer loyalty. To achieve this, firms should value customer complaints, resolve complaints promptly, institute objective and satisfactory complaint handling system, welcome customer suggestions and feedback and establish clear customer complaint lodging and tracking procedure.

(3) The e-services of firms are equally encouraged as many business activities these days are carried out online. Thus, transport companies are encouraged to develop their online booking platforms, online platforms for inquiries, online platform for complaint lodging and functional websites. These among others encourage customer loyalty and limit switching intention

\subsection{Contributions to Knowledge}

The following strengths of this study serve as the contributions to knowledge:

(1) This study attempted to close the gap in the existing literature on customer switching behaviour. This was achieved by following a different dimension away from Insurance (Crosby \& Stephen, 1987), banking (Njoku et al., 2015; KPMG Consulting, 2014; Monye, 2015; Keveney, 1995; Onyeagwara \& Agu, 2017) and the telecommunication (Liang et al., 2013); thus, the transport sector. Studies that focused on the road transport industry are yet to be seen within published marketing literature 
(2) The study proposes this model for road transport firms trying to deal with customer whip and advance trustworthiness. Figure 11 depicts it:

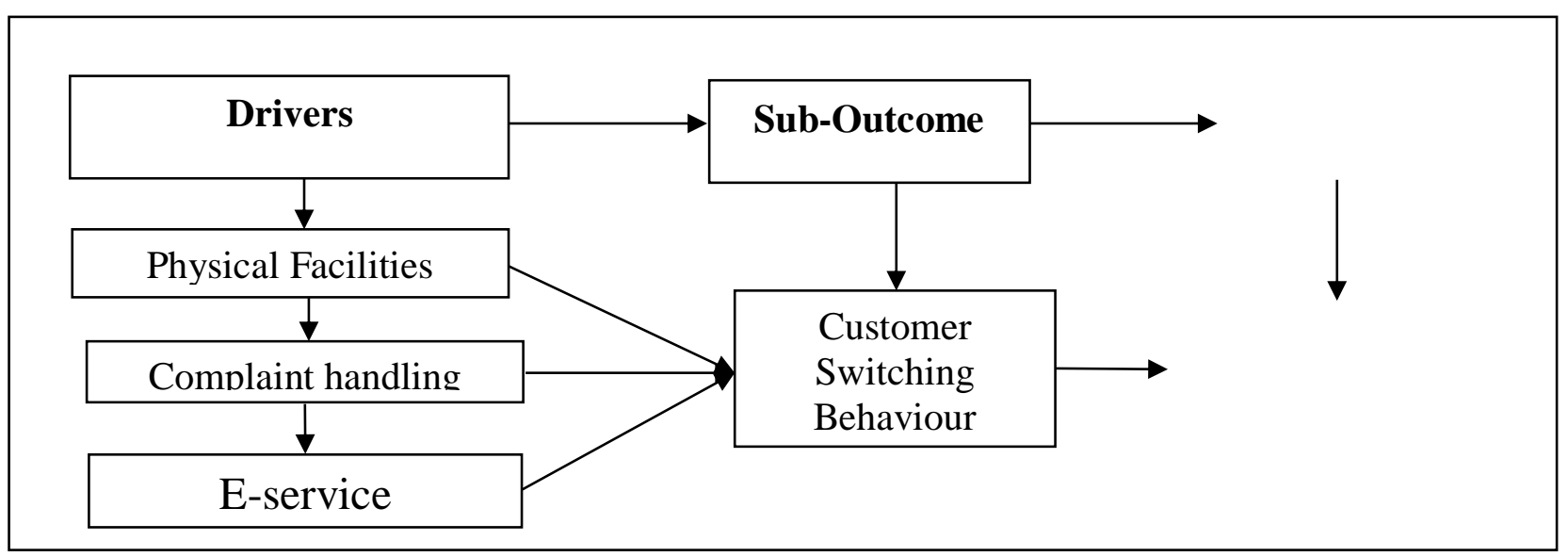

\section{References}

Agu, G. A., Samuel, G. E., \& Ikenna, M. H. (2019). Impact of customer touch point management on banks' performance. Archives of Business Research, 7(3SP), 66-73.

Agu, G. A. (2015). Customer complaint behaviour in the service industry: a study of the customers of the organized road transport firms in Imo State. Ph.D. Thesis, Abia State University, Nigeria.

Anderson, R. E., \& Swaminathan, S. (2011). Customer satisfaction and loyalty in e-markets: A PLS path modelling approach. The Journal of Marketing Theory and Practice, 19(2), 221-234.

Bitner, M. J \& Hubbert, A. R. (1994). Encounter satisfaction versus overall satisfaction versus quality, in Rust, R. T. and Oliver, R. L. (Eds), Service Quality: New Direction in Theory and Practical. Sage: London.

Burnham, T.A., Frels, J.K.,\& Mahajan, V. (2003). Consumer switching costs: A typology, antecedents and consequences. Journal of the Academy of Marketing Science, 2(3), 1-13.

Chu, K. M. (2009). The construction model of customer trust, perceived value and customer loyalty. The Journal of American Academy of Business, Cambridge, 14 (2), 98-103.

CIA. The World Fact book-Greece. Available at http://www.cia.gov/cia/publications/factbook/geos/gr.html

Davidow, M. (2003). Organizational responses to customer complaints: What works and what doesn't. Journal of Service Research, 5(3), 225-250.

Gordon, I.H. 1999, "Relationship Marketing: New Strategies, Techniques and Technologies to Win the Customers You Want and Keep Them Forever", John Wiley and Sons Publishers, 1999.

Hennig-Thurau, T., Malthouse, E. C., Friege, C., Gensler, S., Lobschat, L., Rangaswamy, A., \& Skiera, B. (2010). The impact of new media on customer relationships. Journal of Service Research, 13(3), 311-330.

Hong, J.Y., \& Lee, W. N. (2005). Consumer complaint behaviour in the online environment. Web Systems Design and Online Consumer Behaviour, New Jersey, 2005, 90-105.

Keaveney, S. M. (1995). Customer switching behavior in service industries: an exploratory study. Journal of Marketing, 59 (2), 71-82.

Kumar, A. \& Dash, M. K. (2015). E-service quality dimensions' effect on customers' willingness to buy: structural equation modeling approach. Int. J. Services and Operations Management, 22 (3), 287 - 303.

Njoku, P. O., \& Chiana, C. A. (2019). Investigating the Impact of E-Marketing Adoption on Marketing Success of Small Business Enterprises in Abia State, Nigeria. Archives of Business Research, 7(SP), 90-101. 
Serkan, A. \& Ozer, G. (2005).The analysis of antecedents of customer loyalty in the Turkish mobile telecommunication market. European Journal of Marketing, 39 (7/8), 910-925.

Ward, J. C., \& Ostrom, A. L. (2006). Complaining to the masses: The role of protest framing in customer-created complaint web sites. Journal of Consumer Research, 33(2), 220-230. 